\title{
REVIEWS ON
}

ENVIRONMENTAL

HEALTH

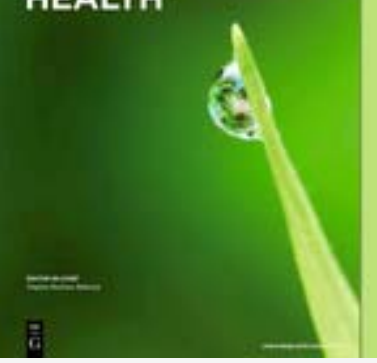

\section{Reviews on Environmental Health}

\author{
Editor-in-Chief: Carpenter, David O. / Sly, Peter
}

Volume 34, Issue 4

\section{Previous Article}

\section{Epigenetic modifications associated with in utero exposure to endocrine disrupting chemicals BPA, DDT and Pb}

Chinonye Doris Onuzulu

\author{
Oluwakemi Anuoluwapo Rotimi
}

Solomon Oladapo Rotimi

Published Online: 2019-05-04 | DOI: https://doi.org/10.1515/reveh-2018-0059

$30,00 € / \$ 42.00 / £ 23.00$

\section{Abstract}

Endocrine disrupting chemicals (EDCs) are xenobiotics which adversely modify the hormone system. The endocrine system is most vulnerable to assaults by endocrine disruptors during the prenatal and early development window, and effects may persist into adulthood and across generations. The prenatal stage is a period of vulnerability to environmental chemicals because the epigenome is usually reprogrammed during this period. Bisphenol A (BPA), lead (Pb), and dichlorodiphenyltrichloroethane (DDT) were chosen for critical review because they have become serious public health concerns globally, especially in Africa where they are widely used without any regulation. In this review, we introduce EDCs and describe the various modes of action of EDCs and the importance of the prenatal and developmental windows to EDC 
exposure. We give a brief overview of epigenetics and describe the various epigenetic mechanisms: DNA methylation, histone modifications and non-coding RNAs, and how each of them affects gene expression. We then summarize findings from previous studies on the effects of prenatal exposure to the endocrine disruptors BPA, Pb and DDT on each of the previously described epigenetic mechanisms. We also discuss how the epigenetic alterations caused by these EDCs may be related to disease processes.

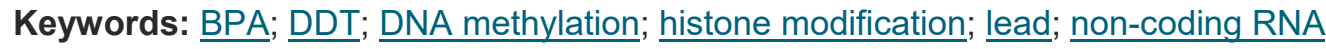

\section{References}

- 1.

Diamanti-Kandarakis E, Bourguignon J-P, Giudice LC, Hauser R, Prins GS, Soto AM, et al. Endocrinedisrupting chemicals: an Endocrine Society scientific statement. Endocr Rev 2009;30(4):293342.PubMedCrossrefGoogle Scholar

- 2.

Eick GN, Thornton JW. Evolution of steroid receptors from an estrogen-sensitive ancestral receptor. Mol Cell Endocrinol 2011;334(1-2):31-8.PubMedCrossrefGoogle Scholar

- 3.

Beausoleil C, Beronius A, Bodin L, Bokkers B, Boon P, Burger M, et al. Review of non-monotonic doseresponses of substances for human risk assessment. EFSA Support Publ

2016;13(5):1027E.Google Scholar

- 4.

Vandenberg LN, Colborn T, Hayes TB, Heindel JJ, Jacobs Jr DR, Lee D-H, et al. Hormones and endocrine-disrupting chemicals: low-dose effects and nonmonotonic dose responses. Endocr Rev 2012;33(3):378-455.CrossrefPubMedGoogle Scholar

- 5 .

Schneider J, Kidd S, Anderson D. Influence of developmental lead exposure on expression of DNA methyltransferases and methyl cytosine-binding proteins in hippocampus. Toxicol Lett 2013;217(1):7581.PubMedCrossrefGoogle Scholar

- 6. 
Welshons WV, Thayer KA, Judy BM, Taylor JA, Curran EM, Vom Saal FS. Large effects from small exposures. I. Mechanisms for endocrine-disrupting chemicals with estrogenic activity. Environ Health Perspect 2003;111(8):994.PubMedCrossrefGoogle Scholar

- 7.

Beato M, Klug J. Steroid hormone receptors: an update. Hum Reprod Update 2000;6(3):22536.PubMedCrossrefGoogle Scholar

- 8.

Moriyama K, Tagami T, Akamizu T, Usui T, Saijo M, Kanamoto N, et al. Thyroid hormone action is disrupted by bisphenol A as an antagonist. J Clin Endocrinol Metab 2002;87(11):518590.PubMedCrossrefGoogle Scholar

- 9.

Schug TT, Janesick A, Blumberg B, Heindel JJ. Endocrine disrupting chemicals and disease susceptibility. J Steroid Biochem Mol Biol 2011;127(3-5):204-15.CrossrefPubMedGoogle Scholar

- 10.

Skinner MK. Role of epigenetics in developmental biology and transgenerational inheritance. Birth

Defects Res C: Embryo Today: Rev 2011;93(1):51-5.CrossrefGoogle Scholar

- 11.

Barker D, Clark PM. Fetal undernutrition and disease in later life. Rev Reprod 1997;2(2):10512.CrossrefPubMedGoogle Scholar

- 12.

Bianco-Miotto T, Craig JM, Gasser YP, van Dijk SJ, Ozanne SE. Epigenetics and DOHaD: from basics to birth and beyond. J Dev Orig Health Dis 2017;8(5):513-9.CrossrefPubMedGoogle Scholar

- 13.

Barouki R. Endocrine disruptors: revisiting concepts and dogma in toxicology. C R Biol 2017;340(910):410-3.PubMedCrossrefGoogle Scholar

- 14. 
Bornman MS, Aneck-Hahn NH, De Jager C, Wagenaar GM, Bouwman H, Barnhoorn IE, et al. Endocrine disruptors and health effects in Africa: a call for action. Environ Health Perspect 2017;125(8):085005. CrossrefGoogle Scholar

- 15.

Waddington $\mathrm{CH}$. The epigenotype. Endeavour 1942;1:18-20.Google Scholar

- 16.

Goldberg AD, Allis CD, Bernstein E. Epigenetics: a landscape takes shape. Cell 2007;128(4):635-

8.CrossrefPubMedGoogle Scholar

- 17.

Hoopes L. Introduction to the gene expression and regulation topic room. Nat Educ 2008;1(1):160. Google Scholar

- 18.

Fazzari MJ, Greally JM. Introduction to epigenomics and epigenome-wide analysis. In: Statistical Methods in Molecular Biology. Totowa, NJ: Humana Press, 2010:243-65.Google Scholar

- 19.

Sweatt JD, Meaney MJ, Nestler EJ, Akbarian S. An overview of the molecular basis of epigenetics.

Epigenetic Regulation in the Nervous System: Basic Mechanisms and Clinical Impact. Cambridge, Massachusetts: Academic Press, 2013:3-33.Google Scholar

- 20.

Rivera RM, Bennett LB. Epigenetics in humans: an overview. Curr Opin Endocrinol Diab Obesity 2010;17(6):493-9.CrossrefGoogle Scholar

- 21.

Kim J, Samaranayake M, Pradhan S. Epigenetic mechanisms in mammals. Cell Mol Life Sci 2009;66(4):596.PubMedCrossrefGoogle Scholar

- 22.

Gibney E, Nolan C. Epigenetics and gene expression. Heredity 2010;105(1):4.CrossrefPubMedGoogle Scholar 
- 23 .

Mazzio EA, Soliman KF. Basic concepts of epigenetics: impact of environmental signals on gene expression. Epigenetics 2012;7(2):119-30.CrossrefPubMedGoogle Scholar

- 24.

Pradhan S, Bacolla A, Wells RD, Roberts RJ. Recombinant human DNA (cytosine-5) methyltransferase I. Expression, purification, and comparison of de novo and maintenance methylation. J Biol Chem 1999;274(46):33002-10.PubMedCrossrefGoogle Scholar

- 25 .

Xu F, Mao C, Ding Y, Rui C, Wu L, Shi A, et al. Molecular and enzymatic profiles of mammalian DNA methyltransferases: structures and targets for drugs. Curr Med Chem 2010;17(33):4052-

71.PubMedGoogle Scholar

- 26.

Siegfried Z, Cedar H. DNA methylation: a molecular lock. Curr Biol 1997;7(5):R305-

7.PubMedCrossrefGoogle Scholar

- 27.

Goll MG, Bestor TH. Eukaryotic cytosine methyltransferases. Annu Rev Biochem 2005;74:481514.PubMedCrossrefGoogle Scholar

- 28.

Sant KE, Goodrich JM. Methods for Analysis of DNA Methylation. In: Toxicoepigenetics. Cambridge, Massachusetts: Academic Press, 2019:347-77.Google Scholar

- 29 .

Kouzarides T. Chromatin modifications and their function. Cell 2007;128(4):693-

705.PubMedCrossrefGoogle Scholar

- 30.

Keating ST, El-Osta A. Epigenetics and metabolism. Circ Res 2015;116(4):715-

36.PubMedCrossrefGoogle Scholar

- 31. 
Azevedo C, Saiardi A. Why always lysine? The ongoing tale of one of the most modified amino acids. Adv Biol Reg 2016;60:144-50.CrossrefGoogle Scholar

- 32 .

Eid A, Bihaqi SW, Renehan WE, Zawia NH. Developmental lead exposure and lifespan alterations in epigenetic regulators and their correspondence to biomarkers of Alzheimer's disease. Alzheimers Dement: Diagn Assess Dis Monit 2016;2:123-31.Google Scholar

- 33.

Pertea M. The human transcriptome: an unfinished story. Genes 2012;3(3):344-

60.CrossrefPubMedGoogle Scholar

- 34.

Ling H, Fabbri M, Calin GA. MicroRNAs and other non-coding RNAs as targets for anticancer drug development. Nat Rev Drug Discov 2013;12(11):847.CrossrefPubMedGoogle Scholar

- 35.

Malumbres M. miRNAs and cancer: an epigenetics view. Mol Aspects Med 2013;34(4):863-

74. CrossrefPubMedGoogle Scholar

- 36 .

Bartel DP. MicroRNAs: target recognition and regulatory functions. Cell 2009;136(2):21533.CrossrefPubMedGoogle Scholar

- 37.

Tammen SA, Friso S, Choi S-W. Epigenetics: the link between nature and nurture. Mol Aspects Med 2013;34(4):753-64.PubMedCrossrefGoogle Scholar

- 38.

Chuang JC, Jones PA. Epigenetics and microRNAs. Pediatr Res 2007;61(5 Part

2):24R.PubMedCrossrefGoogle Scholar

- 39.

Konieczna A, Rutkowska A, Rachon D. Health risk of exposure to Bisphenol A (BPA). Roczniki Państwowego Zakładu Higieny 2015;66(1):5-11.PubMedGoogle Scholar 
- 40 .

Pouokam GB, Ajaezi GC, Mantovani A, Orisakwe OE, Frazzoli C. Use of bisphenol A-containing baby bottles in Cameroon and Nigeria and possible risk management and mitigation measures: community as milestone for prevention. Sci Total Environ 2014;481:296-302.CrossrefPubMedGoogle Scholar

- 41.

Baluka SA, Rumbeiha WK. Bisphenol A and food safety: lessons from developed to developing countries. Food Chem Toxicol 2016;92:58-63.PubMedCrossrefGoogle Scholar

- 42.

Janesick A, Blumberg B. Obesogens, stem cells and the developmental programming of obesity. Int J Androl 2012;35(3):437-48.PubMedCrossrefGoogle Scholar

- 43.

Ross MG, Desai M. Developmental programming of offspring obesity, adipogenesis, and appetite. Clin Obstet Gynecol 2013;56(3):529.PubMedCrossrefGoogle Scholar

- 44 .

Völkel W, Colnot T, Csanády GA, Filser JG, Dekant W. Metabolism and kinetics of bisphenol A in humans at low doses following oral administration. Chem Res Toxicol 2002;15(10):1281-

7.CrossrefPubMedGoogle Scholar

- 45.

Oppeneer SJ, Robien K. Bisphenol A exposure and associations with obesity among adults: a critical review. Public Health Nutr 2015;18(10):1847-63.CrossrefPubMedGoogle Scholar

- 46.

Inoue H, Tsuruta A, Kudo S, Ishii T, Fukushima Y, Iwano H, et al. Bisphenol A glucuronidation and excretion in liver of pregnant and nonpregnant female rats. Drug Metab Disposit 2005;33(1):55-

9.CrossrefGoogle Scholar

- 47.

Strassburg C, Strassburg A, Kneip S, Barut A, Tukey R, Rodeck B, et al. Developmental aspects of human hepatic drug glucuronidation in young children and adults. Gut 2002;50(2):25965. CrossrefPubMedGoogle Scholar 
- 48 .

Burchell B, Coughtrie M, Jackson M, Harding D, Fournel-Gigleux S, Leakey J, et al. Development of human liver UDP-glucuronosyltransferases. Dev Pharmacol Ther 1989;13:70-

7.PubMedCrossrefGoogle Scholar

- 49 .

Pacifici G, Franchi M, Giuliani L, Rane A. Development of the glucuronyltransferase and sulphotransferase towards 2-naphthol in human fetus. Dev Pharmacol Ther 1989;14(2):108-

14.PubMedGoogle Scholar

- 50.

Dolinoy DC, Huang D, Jirtle RL. Maternal nutrient supplementation counteracts bisphenol A-induced DNA hypomethylation in early development. Proc Natl Acad Sci USA 2007;104(32):13056-

61. CrossrefGoogle Scholar

- 51.

Anderson OS, Nahar MS, Faulk C, Jones TR, Liao C, Kannan K, et al. Epigenetic responses following maternal dietary exposure to physiologically relevant levels of bisphenol A. Environ Mol Mutagen

2012;53(5):334-42.CrossrefPubMedGoogle Scholar

- 52.

Bromer JG, Zhou Y, Taylor MB, Doherty L, Taylor HS. Bisphenol-A exposure in utero leads to epigenetic alterations in the developmental programming of uterine estrogen response. FASEB J 2010;24(7):227380.CrossrefPubMedGoogle Scholar

- 53.

Yang B, Li S-Z, Ma L, Liu H-L, Liu J, Shao J-J. Expression and mechanism of action of miR-196a in epithelial ovarian cancer. Asian Pac J Trop Med 2016;9(11):1105-10.CrossrefPubMedGoogle Scholar

- 54 .

Dhimolea E, Wadia PR, Murray TJ, Settles ML, Treitman JD, Sonnenschein C, et al. Prenatal exposure to BPA alters the epigenome of the rat mammary gland and increases the propensity to neoplastic development. PLoS One 2014;9(7):e99800.PubMedCrossrefGoogle Scholar

- 55. 
Strakovsky RS, Wang H, Engeseth NJ, Flaws JA, Helferich WG, Pan Y-X, et al. Developmental bisphenol A (BPA) exposure leads to sex-specific modification of hepatic gene expression and epigenome at birth that may exacerbate high-fat diet-induced hepatic steatosis. Toxicol Appl Pharmacol 2015;284(2):10112.PubMedCrossrefGoogle Scholar

- 56.

Rotimi OA, Rotimi SO, Duru CU, Ebebeinwe OJ, Abiodun AO, Oyeniyi BO, et al. Acute aflatoxin B1induced hepatotoxicity alters gene expression and disrupts lipid and lipoprotein metabolism in rats. Toxicol Rep 2017;4:408-14.CrossrefPubMedGoogle Scholar

- 57.

Koves TR, Ussher JR, Noland RC, Slentz D, Mosedale M, Ilkayeva O, et al. Mitochondrial overload and incomplete fatty acid oxidation contribute to skeletal muscle insulin resistance. Cell Metab 2008;7(1):4556.CrossrefPubMedGoogle Scholar

- 58. Kuhajda FP, Ronnett GV. Modulation of carnitine palmitoyltransferase-1 for the treatment of obesity. Curr Opin Invest Drugs (London, England: 2000) 2007;8(4):312-7.Google Scholar

- 59 .

Junge KM, Leppert B, Jahreis S, Wissenbach DK, Feltens R, Grützmann K, et al. MEST mediates the impact of prenatal bisphenol A exposure on long-term body weight development. Clin Epigenetics 2018;10(1):58.CrossrefPubMedGoogle Scholar

- 60.

Bauer T, Trump S, Ishaque N, Thürmann L, Gu L, Bauer M, et al. Environment-induced epigenetic reprogramming in genomic regulatory elements in smoking mothers and their children. Mol Syst Biol 2016;12(3):861.CrossrefPubMedGoogle Scholar

- 61.

Kamei Y, Suganami T, Kohda T, Ishino F, Yasuda K, Miura S, et al. Peg1/Mest in obese adipose tissue is expressed from the paternal allele in an isoform-specific manner. FEBS Lett 2007;581(1):916.CrossrefGoogle Scholar

- 62. 
Soubry A, Murphy S, Wang F, Huang Z, Vidal A, Fuemmeler B, et al. Newborns of obese parents have altered DNA methylation patterns at imprinted genes. Int J Obes 2015;39(4):650.CrossrefGoogle Scholar

- 63.

Karbiener M, Glantschnig C, Pisani DF, Laurencikiene J, Dahlman I, Herzig S, et al. Mesoderm-specific transcript (MEST) is a negative regulator of human adipocyte differentiation. Int $\mathrm{J}$ Obes 2015;39(12):1733.CrossrefGoogle Scholar

- 64 .

Takahashi M, Kamei Y, Ezaki O. Mest/Peg1 imprinted gene enlarges adipocytes and is a marker of adipocyte size. Am J Physiol Endocrinol Metab 2005;288(1):E117-24.PubMedCrossrefGoogle Scholar

- 65.

Kadota Y, Kawakami T, Suzuki S, Sato M. Involvement of mesoderm-specific transcript in cell growth of 3T3-L1 preadipocytes. J Health Sci 2009;55(5):814-9.CrossrefGoogle Scholar

- 66.

Mao Z, Xia W, Huo W, Zheng T, Bassig BA, Chang H, et al. Pancreatic impairment and lgf2 hypermethylation induced by developmental exposure to bisphenol A can be counteracted by maternal folate supplementation. J Appl Toxicol 2017;37(7):825-35.CrossrefPubMedGoogle Scholar

- 67.

Devedjian J-C, George M, Casellas A, Pujol A, Visa J, Pelegrín M, et al. Transgenic mice overexpressing insulin-like growth factor-II in $\beta$ cells develop type 2 diabetes. J Clin Invest 2000;105(6):73140.CrossrefPubMedGoogle Scholar

- 68 .

Serradas P, Goya L, Lacorne M, Gangnerau MN, Ramos S, Álvarez C, et al. Insulin-like growth factor 2 production is impaired in fetal GK rats. Diabetologia 2000;43:A131. Google Scholar

- 69.

Calderari S, Gangnerau M-N, Thibault M, Meile M-J, Kassis N, Alvarez C, et al. Defective IGF2 and IGF1R protein production in embryonic pancreas precedes beta cell mass anomaly in the Goto-Kakizaki rat model of type 2 diabetes. Diabetologia 2007;50(7):1463-71.CrossrefPubMedGoogle Scholar 
Liu S, Mauvais-Jarvis F. Minireview: estrogenic protection of $\beta$-cell failure in metabolic diseases. Endocrinology 2009;151(3):859-64.PubMedGoogle Scholar

- 71.

Faulk C, Kim JH, Jones TR, McEachin RC, Nahar MS, Dolinoy DC, et al. Bisphenol A-associated alterations in genome-wide DNA methylation and gene expression patterns reveal sequence-dependent and non-monotonic effects in human fetal liver. Environ Epigenet 2015;1(1):dvv006.CrossrefPubMedGoogle Scholar

- 72 .

Faulk C, Kim JH, Anderson OS, Nahar MS, Jones TR, Sartor MA, et al. Detection of differential DNA methylation in repetitive DNA of mice and humans perinatally exposed to bisphenol A. Epigenetics 2016;11(7):489-500.PubMedCrossrefGoogle Scholar

- 73.

Nahar MS, Liao C, Kannan K, Harris C, Dolinoy DC. In utero bisphenol A concentration, metabolism, and global DNA methylation across matched placenta, kidney, and liver in the human fetus. Chemosphere 2015;124:54-60.PubMedCrossrefGoogle Scholar

- 74 .

Doherty LF, Bromer JG, Zhou Y, Aldad TS, Taylor HS. In utero exposure to diethylstilbestrol (DES) or bisphenol-A (BPA) increases EZH2 expression in the mammary gland: an epigenetic mechanism linking endocrine disruptors to breast cancer. Hormones Cancer 2010;1(3):14655.PubMedCrossrefGoogle Scholar

- 75.

Veiga-Lopez A, Luense LJ, Christenson LK, Padmanabhan V. Developmental programming: gestational bisphenol-A treatment alters trajectory of fetal ovarian gene expression. Endocrinology 2013;154(5):1873-84.PubMedCrossrefGoogle Scholar

- 76.

De Felice B, Manfellotto F, Palumbo A, Troisi J, Zullo F, Di Carlo C, et al. Genome-wide microRNA expression profiling in placentas from pregnant women exposed to BPA. BMC Med Genomics 2015;8(1):56.CrossrefPubMedGoogle Scholar 
- 77.

Avissar-Whiting M, Veiga KR, Uhl KM, Maccani MA, Gagne LA, Moen EL, et al. Bisphenol A exposure leads to specific microRNA alterations in placental cells. Reprod Toxicol 2010;29(4):4016.PubMedCrossrefGoogle Scholar

- 78.

Flora G, Gupta D, Tiwari A. Toxicity of lead: a review with recent updates. Interdiscip Toxicol 2012;5(2):47-58.PubMedCrossrefGoogle Scholar

- 79 .

Dooyema CA, Neri A, Lo Y-C, Durant J, Dargan PI, Swarthout T, et al. Outbreak of fatal childhood lead poisoning related to artisanal gold mining in northwestern Nigeria, 2010. Environ Health Perspect 2012;120(4):601.CrossrefPubMedGoogle Scholar

- 80.

Stein J, Schettler T, Wallinga D, Valenti M. In harm's way: toxic threats to child development. J Dev Behav Pediatr 2002;23:S13-22.PubMedCrossrefGoogle Scholar

- 81.

Goyer RA. Transplacental transport of lead. Environ Health Perspect 1990;89:101.PubMedCrossrefGoogle Scholar

- 82.

Nigg JT, Nikolas M, Mark Knottnerus G, Cavanagh K, Friderici K. Confirmation and extension of association of blood lead with attention-deficit/hyperactivity disorder (ADHD) and ADHD symptom domains at population-typical exposure levels. J Child Psychol Psychiatry 2010;51(1):5865.CrossrefPubMedGoogle Scholar

- 83.

Surkan PJ, Zhang A, Trachtenberg F, Daniel DB, McKinlay S, Bellinger DC. Neuropsychological function in children with blood lead levels $<10 \mu \mathrm{g} / \mathrm{dL}$. Neurotoxicology 2007;28(6):1170-7.CrossrefGoogle Scholar

- 84. 
Mazumdar M, Bellinger DC, Gregas M, Abanilla K, Bacic J, Needleman HL. Low-level environmental lead exposure in childhood and adult intellectual function: a follow-up study. Environ Health 2011;10(1):24.PubMedCrossrefGoogle Scholar

- 85.

Ross JP, Rand KN, Molloy PL. Hypomethylation of repeated DNA sequences in cancer. Epigenomics 2010;2(2):245-69.CrossrefPubMedGoogle Scholar

- 86.

Rebollo R, Miceli-Royer K, Zhang Y, Farivar S, Gagnier L, Mager DL. Epigenetic interplay between mouse endogenous retroviruses and host genes. Genome Biol 2012;13(10):R89.CrossrefPubMedGoogle Scholar

- 87.

Rebollo R, Mager DL. Methylated DNA immunoprecipitation analysis of mammalian endogenous retroviruses. In: Transposons and Retrotransposons. New York, NY: Humana Press, 2016:37785. Google Scholar

- 88.

Ostertag EM, Kazazian Jr HH. Biology of mammalian L1 retrotransposons. Annu Rev Genet 2001;35(1):501-38.PubMedCrossrefGoogle Scholar

- 89.

Zhang Y, Maksakova IA, Gagnier L, Van De Lagemaat LN, Mager DL. Genome-wide assessments reveal extremely high levels of polymorphism of two active families of mouse endogenous retroviral elements.

PLoS Genet 2008;4(2):e1000007.PubMedCrossrefGoogle Scholar

- 90.

Montrose L, Faulk C, Francis J, Dolinoy D. Perinatal lead $(\mathrm{Pb})$ exposure results in sex and tissuedependent adult DNA methylation alterations in murine IAP transposons. Environ Mol Mutagen 2017;58(8):540-50.CrossrefPubMedGoogle Scholar

- 91. 
Markowski DN, Thies HW, Gottlieb A, Wenk H, Wischnewsky M, Bullerdiek J. HMGA2 expression in white adipose tissue linking cellular senescence with diabetes. Genes Nutr 2013;8(5):449.CrossrefPubMedGoogle Scholar

- 92.

Luca G, Haba-Rubio J, Dauvilliers Y, Lammers GJ, Overeem S, Donjacour CE, et al. Clinical, polysomnographic and genome-wide association analyses of narcolepsy with cataplexy: a European Narcolepsy Network study. J Sleep Res 2013;22(5):482-95.CrossrefPubMedGoogle Scholar

- 93.

Nye MD, King KE, Darrah TH, Maguire R, Jima DD, Huang Z, et al. Maternal blood lead concentrations, DNA methylation of MEG3 DMR regulating the DLK1/MEG3 imprinted domain and early growth in a multiethnic cohort. Environ Epigenetics 2016;2(1):dvv009. Google Scholar

- 94.

Engström K, Rydbeck F, Kippler M, Wojdacz TK, Arifeen S, Vahter M, et al. Prenatal lead exposure is associated with decreased cord blood DNA methylation of the glycoprotein VI gene involved in platelet activation and thrombus formation. Environ Epigenet 2015;1(1):1-9 [dvv007].Google Scholar

- 95.

Berndt M, Metharom P, Andrews R. Primary haemostasis: newer insights. Haemophilia 2014;20:1522. CrossrefPubMedGoogle Scholar

- 96.

Loyau S, Dumont B, Ollivier V, Boulaftali Y, Feldman L, Ajzenberg N, et al. Platelet glycoprotein VI dimerization, an active process inducing receptor competence, is an indicator of platelet reactivity. Arter Thromb Vasc Biol 2012;32(3):778-5.CrossrefGoogle Scholar

- 97.

Bigalke B, Lindemann S, Ehlers R, Seizer P, Daub K, Langer H, et al. Expression of platelet collagen receptor glycoprotein VI is associated with acute coronary syndrome. Eur Heart J 2006;27(18):21659.CrossrefPubMedGoogle Scholar

- 98. 
Bigalke B, Geisler T, Stellos K, Langer H, Daub K, Kremmer E, et al. Platelet collagen receptor glycoprotein $\mathrm{VI}$ as a possible novel indicator for the acute coronary syndrome. Am Heart $\mathrm{J}$ 2008;156(1):193-200.CrossrefGoogle Scholar

- 99.

Bigalke B, Stellos K, Geisler T, Lindemann S, May AE, Gawaz M. Glycoprotein VI as a prognostic biomarker for cardiovascular death in patients with symptomatic coronary artery disease. Clin Res Cardiol 2010;99(4):227-33. CrossrefGoogle Scholar

- 100.

Pilsner JR, Hu H, Ettinger A, Sánchez BN, Wright RO, Cantonwine D, et al. Influence of prenatal lead exposure on genomic methylation of cord blood DNA. Environ Health Perspect 2009;117(9):1466.PubMedCrossrefGoogle Scholar

- 101.

Wilson AS, Power BE, Molloy PL. DNA hypomethylation and human diseases. Biochim Biophys Acta: Rev Cancer 2007;1775(1):138-62. Google Scholar

- 102.

Sen A, Cingolani P, Senut M-C, Land S, Mercado-Garcia A, Tellez-Rojo MM, et al. Lead exposure induces changes in 5-hydroxymethylcytosine clusters in $\mathrm{CpG}$ islands in human embryonic stem cells and umbilical cord blood. Epigenetics 2015;10(7):607-21.CrossrefPubMedGoogle Scholar

- 103.

Sen A, Heredia N, Senut M-C, Hess M, Land S, Qu W, et al. Early life lead exposure causes genderspecific changes in the DNA methylation profile of DNA extracted from dried blood spots. Epigenomics 2015;7(3):379-93.CrossrefPubMedGoogle Scholar

- 104.

Yamamoto H, Kokame K, Okuda T, Nakajo Y, Yanamoto H, Miyata T. NDRG4 protein-deficient mice exhibit spatial learning deficits and vulnerabilities to cerebral ischemia. J Biol Chem 2011;286(29):2615865.CrossrefPubMedGoogle Scholar

- 105. 
Araki T, Milbrandt J. Ninjurin2, a novel homophilic adhesion molecule, is expressed in mature sensory and enteric neurons and promotes neurite outgrowth. J Neurosci 2000;20(1):18795.CrossrefPubMedGoogle Scholar

- 106.

Lin K-P, Chen S-Y, Lai L-C, Huang Y-L, Chen J-H, Chen T-F, et al. Genetic polymorphisms of a novel vascular susceptibility gene, Ninjurin2 (NINJ2), are associated with a decreased risk of Alzheimer's disease. PLoS One 2011;6(6):e20573.CrossrefPubMedGoogle Scholar

- 107.

Sen A, Heredia N, Senut M-C, Land S, Hollocher K, Lu X, et al. Multigenerational epigenetic inheritance in humans: DNA methylation changes associated with maternal exposure to lead can be transmitted to the grandchildren. Sci Rep 2015;5:14466.CrossrefPubMedGoogle Scholar

- 108.

Sánchez-Martín FJ, Lindquist DM, Landero-Figueroa J, Zhang X, Chen J, Cecil KM, et al. Sex-and tissuespecific methylome changes in brains of mice perinatally exposed to lead. Neurotoxicology 2015;46:92100.PubMedCrossrefGoogle Scholar

- 109.

Auger CJ, Auger AP. Permanent and plastic epigenesis in neuroendocrine systems. Front Neuroendocrinol 2013;34(3):190-7.PubMedCrossrefGoogle Scholar

- 110.

Chung WC, Auger AP. Gender differences in neurodevelopment and epigenetics. Pflügers Archiv Eur J Physiol 2013;465(5):573-84.CrossrefGoogle Scholar

- 111.

Menger Y, Bettscheider M, Murgatroyd C, Spengler D. Sex differences in brain epigenetics. Epigenomics 2010;2(6):807-21.CrossrefPubMedGoogle Scholar

- 112.

Schneider J, Anderson D, Sonnenahalli H, Vadigepalli R. Sex-based differences in gene expression in hippocampus following postnatal lead exposure. Toxicol Appl Pharmacol 2011;256(2):179_ 90.CrossrefPubMedGoogle Scholar 
- 113.

Schneider J, Mettil W, Anderson D. Differential effect of postnatal lead exposure on gene expression in the hippocampus and frontal cortex. J Mol Neurosci 2012;47(1):76-88.CrossrefPubMedGoogle Scholar

- 114 .

Schneider JS, Anderson DW, Talsania K, Mettil W, Vadigepalli R. Effects of developmental lead exposure on the hippocampal transcriptome: influences of sex, developmental period, and lead exposure level. Toxicol Sci 2012;129(1):108-25.PubMedCrossrefGoogle Scholar

- 115.

Feng J, Chang H, Li E, Fan G. Dynamic expression of de novo DNA methyltransferases Dnmt3a and Dnmt3b in the central nervous system. J Neurosci Res 2005;79(6):734-

46.PubMedCrossrefGoogle Scholar

- 116.

Feng J, Fouse S, Fan G. Epigenetic regulation of neural gene expression and neuronal function. Pediat Res 2007; 61(5 Part 2):58R.CrossrefGoogle Scholar

- 117.

Yasui DH, Peddada S, Bieda MC, Vallero RO, Hogart A, Nagarajan RP, et al. Integrated epigenomic analyses of neuronal MeCP2 reveal a role for long-range interaction with active genes. Proc Natl Acad Sci USA 2007;104(49):19416-21.CrossrefGoogle Scholar

- 118.

Nagarajan R, Hogart A, Gwye Y, Martin MR, LaSalle JM. Reduced MeCP2 expression is frequent in autism frontal cortex and correlates with aberrant MECP2 promoter methylation. Epigenetics 2006;1(4):172-82.CrossrefGoogle Scholar

- 119.

Luo M, Xu Y, Cai R, Tang Y, Ge M-M, Liu Z-H, et al. Epigenetic histone modification regulates developmental lead exposure induced hyperactivity in rats. Toxicol Lett 2014;225(1):7885.PubMedCrossrefGoogle Scholar

- 120. 
Li Q, Kappil MA, Li A, Dassanayake PS, Darrah TH, Friedman AE, et al. Exploring the associations between microRNA expression profiles and environmental pollutants in human placenta from the National Children's Study (NCS). Epigenetics 2015;10(9):793-802.CrossrefPubMedGoogle Scholar

- 121.

Wulczyn FG, Smirnova L, Rybak A, Brandt C, Kwidzinski E, Ninnemann O, et al. Post-transcriptional regulation of the let-7 microRNA during neural cell specification. FASEB J 2007;21(2):41526.CrossrefPubMedGoogle Scholar

- 122.

Ventayol M, Viñas JL, Sola A, Jung M, Brüne B, Pi F, et al. miRNA let-7e targeting MMP9 is involved in adipose-derived stem cell differentiation toward epithelia. Cell Death Dis 2014;5(2):e1048.CrossrefPubMedGoogle Scholar

- 123.

Worringer KA, Rand TA, Hayashi Y, Sami S, Takahashi K, Tanabe K, et al. The let-7/LIN-41 pathway regulates reprogramming to human induced pluripotent stem cells by controlling expression of prodifferentiation genes. Cell Stem Cell 2014;14(1):40-52.PubMedCrossrefGoogle Scholar

- 124.

Shi X-B, Tepper CG, deVere White RW. Cancerous miRNAs and their regulation. Cell Cycle 2008;7(11):1529-38.PubMedCrossrefGoogle Scholar

125.

Pietrzykowski AZ, Spijker S. Impulsivity and comorbid traits: a multi-step approach for finding putative responsible microRNAs in the amygdala. Front Neurosci 2014;8:389.PubMedGoogle Scholar

- 126.

Roy A, Bellinger D, Hu H, Schwartz J, Ettinger AS, Wright RO, et al. Lead exposure and behavior among young children in Chennai, India. Environ Health Perspect 2009;117(10):1607.PubMedCrossrefGoogle Scholar

Wu J, Ying T, Shen Z, Wang H. Effect of low-level prenatal mercury exposure on neonate neurobehavioral development in China. Pediat Neurol 2014;51(1):93-9.CrossrefGoogle Scholar 
- 128.

Suzuki K, Nakai K, Sugawara T, Nakamura T, Ohba T, Shimada M, et al. Neurobehavioral effects of prenatal exposure to methylmercury and PCBs, and seafood intake: neonatal behavioral assessment scale results of Tohoku study of child development. Environ Res 2010;110(7):699_ 704.PubMedCrossrefGoogle Scholar

- 129.

Wasserman GA, Staghezza-Jaramillo B, Shrout P, Popovac D, Graziano J. The effect of lead exposure on behavior problems in preschool children. Am J Publ Health 1998;88(3):481-6.CrossrefGoogle Scholar

- 130.

Van Dyk J, Bouwman H, Barnhoorn I, Bornman M. DDT contamination from indoor residual spraying for malaria control. Sci Total Environ 2010;408(13):2745-52.CrossrefPubMedGoogle Scholar

- 131.

Skinner MK, Manikkam M, Tracey R, Guerrero-Bosagna C, Haque M, Nilsson EE. Ancestral dichlorodiphenyltrichloroethane (DDT) exposure promotes epigenetic transgenerational inheritance of obesity. BMC Med 2013;11(1):228. CrossrefPubMedGoogle Scholar

Skinner MK, Maamar MB, Sadler-Riggleman I, Beck D, Nilsson E, McBirney M, et al. Alterations in sperm DNA methylation, non-coding RNA and histone retention associate with DDT-induced epigenetic transgenerational inheritance of disease. Epigenetics Chromatin 2018;11(1):8.CrossrefPubMedGoogle Scholar

- 133.

Huen K, Yousefi P, Bradman A, Yan L, Harley KG, Kogut K, et al. Effects of age, sex, and persistent organic pollutants on DNA methylation in children. Environ Mol Mutagen 2014;55(3):209_ 22.PubMedCrossrefGoogle Scholar

- 134.

Wilhelm CS, Kelsey KT, Butler R, Plaza S, Gagne L, Zens MS, et al. Implications of LINE1 methylation for bladder cancer risk in women. Clin Cancer Res 2010;16(5):1682-9.CrossrefPubMedGoogle Scholar 
El-Maarri O, Walier M, Behne F, van Üüm J, Singer H, Diaz-Lacava A, et al. Methylation at global LINE-1 repeats in human blood are affected by gender but not by age or natural hormone cycles. PLoS One 2011;6(1):e16252.PubMedCrossrefGoogle Scholar

- 136.

Zhang FF, Cardarelli R, Carroll J, Fulda KG, Kaur M, Gonzalez K, et al. Significant differences in global genomic DNA methylation by gender and race/ethnicity in peripheral blood. Epigenetics 2011;6(5):6239.CrossrefGoogle Scholar

- 137.

Burris HH, Rifas-Shiman SL, Baccarelli A, Boeke CE, Kleinman K, Wen X, et al. Associations of LINE-1 ("Global") DNA methylation with preterm birth in a prospective cohort study. J Dev Origins Health Dis 2011: Cambridge: Cambridge University Press; 2011:S62.Google Scholar

- 138.

Singer H, Walier M, Nüsgen N, Meesters C, Schreiner F, Woelfle J, et al. Methylation of L1Hs promoters is lower on the inactive $\mathrm{X}$, has a tendency of being higher on autosomes in smaller genomes and shows inter-individual variability at some loci. Human Mol Gene 2011;21(1):219-35. Google Scholar

- 139.

Kappil MA, Li Q, Li A, Dassanayake PS, Xia Y, Nanes JA, et al. In utero exposures to environmental organic pollutants disrupt epigenetic marks linked to fetoplacental development. Environ Epigenet 2016;2(1):dvv013.CrossrefPubMedGoogle Scholar

- 140.

Zhang L, Long X. Association of BRCA1 promoter methylation with sporadic breast cancers: evidence from 40 studies. Sci Rep 2015;5:17869.PubMedGoogle Scholar

- 141.

Mirza S, Sharma G, Prasad CP, Parshad R, Srivastava A, Gupta SD, et al. Promoter hypermethylation of TMS1, BRCA1, ER $\alpha$ and PRB in serum and tumor DNA of invasive ductal breast carcinoma patients. Life Sci 2007;81(4):280-7.CrossrefPubMedGoogle Scholar 
Wolff M. Half-lives of organochlorines (OCs) in humans. Arch Environ Contamin Toxicol 1999;36(4):504.Google Scholar

- 143.

Yu X, Zhao B, Su Y, Zhang Y, Chen J, Wu W, et al. Association of prenatal organochlorine pesticidedichlorodiphenyltrichloroethane exposure with fetal genome-wide DNA methylation. Life Sci 2018;200:816.PubMedCrossrefGoogle Scholar

- 144.

Hammoud SS, Nix DA, Hammoud AO, Gibson M, Cairns BR, Carrell DT. Genome-wide analysis identifies changes in histone retention and epigenetic modifications at developmental and imprinted gene loci in the sperm of infertile men. Human Reprod 2011;26(9):2558-69.CrossrefGoogle Scholar

- 145.

Jenkins TG, Carrell DT. The paternal epigenome and embryogenesis: poising mechanisms for development. Asian J Androl 2011;13(1):76.CrossrefPubMedGoogle Scholar

- 146.

Ben Maamar M, Sadler-Riggleman I, Beck D, Skinner MK.Epigenetic transgenerational inheritance of altered sperm histone retention sites. Sci Rep 2018;8(1):5308.CrossrefPubMedGoogle Scholar

- 147.

Yan W. Potential roles of noncoding RNAs in environmental epigenetic transgenerational inheritance. Mol Cell Endocrinol 2014;398(1-2):24-30.PubMedCrossrefGoogle Scholar

- 148 .

Dallaire A, Simard MJ. The implication of microRNAs and endo-siRNAs in animal germline and early development. Dev Biol 2016;416(1):18-25.CrossrefPubMedGoogle Scholar

- 149 .

Marsit CJ. Influence of environmental exposure on human epigenetic regulation. J Exp Biol 2015;218(1):71-9.CrossrefPubMedGoogle Scholar

- 150. 
Valinluck V, Tsai H-H, Rogstad DK, Burdzy A, Bird A, Sowers LC. Oxidative damage to methyl-CpG sequences inhibits the binding of the methyl-CpG binding domain (MBD) of methyl-CpG binding protein 2 (MeCP2). Nucleic Acids Res 2004;32(14):4100-8.CrossrefPubMedGoogle Scholar

- 151.

Valinluck V, Sowers LC. Endogenous cytosine damage products alter the site selectivity of human DNA maintenance methyltransferase DNMT1. Cancer Res 2007;67(3):946-

50.PubMedCrossrefGoogle Scholar

- 152.

Florl AR, Löwer R, Schmitz-Dräger B, Schulz W. DNA methylation and expression of LINE-1 and HERV-K provirus sequences in urothelial and renal cell carcinomas. Br J Cancer 1999;80(9):1312.PubMedCrossrefGoogle Scholar

- 153.

Colot V, Rossignol JL. Eukaryotic DNA methylation as an evolutionary device. Bioessays 1999;21(5):402-11.CrossrefPubMedGoogle Scholar

- 154.

Domínguez-Bendala J, McWhir J. Enhanced gene targeting frequency in ES cells with low genomic methylation levels. Transgen Res 2004;13(1):69-74.CrossrefGoogle Scholar

- 155.

Maloisel L, Rossignol J-L. Suppression of crossing-over by DNA methylation in Ascobolus. Genes Dev 1998;12(9):1381-9.PubMedCrossrefGoogle Scholar

- 156.

Hahn MA, Szabo PE, Pfeifer GP. 5-Hydroxymethylcytosine: a stable or transient DNA modification? Genomics 2014;104(5):314-23.PubMedCrossrefGoogle Scholar

- 157.

Wu H, D'Alessio AC, Ito S, Wang Z, Cui K, Zhao K, et al. Genome-wide analysis of 5hydroxymethylcytosine distribution reveals its dual function in transcriptional regulation in mouse embryonic stem cells. Genes Dev 2011;25(7):679-84.PubMedCrossrefGoogle Scholar 
Abdel-Maksoud FM, Leasor KR, Butzen K, Braden TD, Akingbemi BT. Prenatal exposures of male rats to the environmental chemicals bisphenol $\mathrm{A}$ and $\mathrm{Di}(2$-ethylhexyl) phthalate impact the sexual differentiation process. Endocrinology 2015;156(12):4672-83.CrossrefPubMedGoogle Scholar

- 159.

Kochmanski JJ, Marchlewicz EH, Cavalcante RG, Perera BP, Sartor MA, Dolinoy DC. Longitudinal effects of developmental bisphenol A exposure on epigenome-wide DNA hydroxymethylation at imprinted loci in mouse blood. Environ Health Perspect 2018;126(7):077006.PubMedCrossrefGoogle Scholar

\section{About the article}

Received: 2018-09-21

Accepted: 2019-04-03

Published Online: 2019-05-04

Published in Print: 2019-12-18

Research funding: Authors state no funding involved.

Conflict of interest: Authors state no conflict of interest.

Informed consent: Not applicable.

Ethical approval: The conducted research is not related to either human or animal use.

Citation Information: Reviews on Environmental Health, Volume 34, Issue 4, Pages 309-325, ISSN

(Online) 2191-0308, ISSN (Print) 0048-7554, DOI: https://doi.org/10.1515/reveh-2018-0059.

Export Citation

(C2019 Walter de Gruyter GmbH, Berlin/Boston.

Get Permission

\section{We recommend}

1. Misregulated inflammation as an outcome of early-life exposure to endocrine-disrupting chemicals

Rodney R. Dietert, Reviews on Environmental Health, 2012

2. Endocrine control of epigenetic mechanisms in male reproduction 
Mandar Ankolkar et al., Hormone Molecular Biology and Clinical Investigation, 2016

3. Endocrine disruption in wild freshwater fish

S. Jobling et al., Pure and Applied Chemistry, 2003

4. Exposure to the endocrine disruptor bisphenol A alters susceptibility for mammary cancer

Coral A. Lamartiniere et al., Hormone Molecular Biology and Clinical Investigation, 2011

5. Prenatal exposure to bisphenol A alters mouse fetal pancreatic morphology and islet composition

Rebecca Whitehead et al., Hormone Molecular Biology and Clinical Investigation, 2016

1. Research progress in correlation between early life exposure to environmental endocrine disruptor chemicals and allergic diseases in children

TANG Ning et al., Journal of Shanghai Jiaotong University (Medical Science), 2019

2. Endocrine-disrupting chemicals: experts debate health threats

Healio

3. Endocrine-disrupting chemical exposure increases risk for diabetes, obesity, hormonal cancers

Healio

4. Exposure to Environmental Endocrine Disruptors and Child Development

John D. Meeker et al., JAMA Pediatrics, 2012

5. Endocrine Disruptors as Potentially Modifiable Diabetes Risk Factors

PracticeUpdate, 2019

- Privacy Statement

- Terms and Conditions

- Disclaimer

- House Rules

Copyright (c) 2011-2020 by Walter de Gruyter GmbH

Powered by PubFactory 